\title{
ANALISIS DISTRIBUSI TENAGA KESEHATAN (DOKTER PERAWAT DAN BIDAN) DI INDONESIA PADA 2013 DENGAN MENGGUNAKAN GINI INDEX
}

\author{
Health Workforce Distribution (Physicians, Nurses Midwives) Analysis \\ in Indonesia 2013 by Gini Index
}

\author{
Asep Hermawan \\ Puslitbang Upaya Kesehatan Masyarakat, Badan Litbang Kesehatan, Jln Percetakan Negara 29, Jakarta Pusat \\ Naskah masuk: 6 Februari 2019 Perbaikan: 11 Juni 2019 Layak terbit: 18 Juli 2019 \\ http://dx.doi.org/10.22435/hsr.v22i3.1304
}

\begin{abstract}
ABSTRAK
Distribusi dokter, perawat dan bidan yang merata merupakan salah satu kunci sukses untuk mencapai 12 indikator kesehatan masyarakat yang ditetapkan World Health Organization. Tujuan penelitian ini adalah menggambarkan pemerataan tenaga dokter, perawat dan bidan di Indonesia pada 2013. Sumber data tenaga kesehatan (dokter perawat dan bidan) diperoleh dari data rutin Badan Pengembangan dan Pendayagunaan Sumber Daya Manusia Kesehatan (BPPSDMK) 2013. Data jumlah penduduk diperoleh dari Lampiran 1 Buku Induk Kode dan Data Wilayah Administrasi Pemerintahan per Provinsi, Kabupaten/Kota dan Kecamatan Seluruh Indonesia milik Kementerian Dalam Negeri. Untuk menilai inequality distribusi tenaga kesehatan menggunakan rasio/populasi, Gini Index dan Kurva Lorenz. Hasil penelitian menunjukkan bahwa rasio bidan dan perawat/100.000 penduduk sudah memenuhi target RPJMN 2010-2014, sedangkan dokter masih jauh dari target. Analisis dengan Gini Index menunjukkan bahwa distribusi bidan lebih dibandingkan tenaga kesehatan lainnya. Regional Nusa Tenggara memiliki inequality tenaga yang tertinggi dibandingkan regional lainnya baik untuk dokter, perawat, dan bidan. Secara administratif, kota cenderung lebih merata untuk semua jenis tenaga kesehatan. Berdasarkan status daerah tertinggal, perbatasan dan kepulauan (DTPK), daerah non DTPK cenderung lebih merata dibandingkan DTPK. Walaupun secara rasio per populasi sebagian tenaga kesehatan sudah mencukupi namun tidak terdistribusi dengan baik. Penilaian distribusi tenaga kesehatan seharusnya tidak hanya menggunakan rasio tenaga per populasi saja, penggunaan ukuran indeks distribusi lain seperti Gini Index dan ukuran distribusi lain akan dapat memberi opsi kebijakan lebih baik.
\end{abstract}

Kata kunci: Inequility; Gini Index; Kurva lorenz; Tenaga Kesehatan

\begin{abstract}
Equal distributions of physicians, nurses and midwives are the successful key to achieve the 12 public health indicators set by the World Health Organization. This study is to measure physicians, nurses and midwives inequality in Indonesia, 2013. Data for health workforce are obtained from routine data by the Board for Development and Empowerment of Human Resources for Health, 2013, and population data from Appendix 1 Books Code and Region Administration Data by Province, districs/cities and all Indonesian Sub-district, Ministry of Internal Affairs. Ratio per Population, Gini Index and Lorenz's curve were used to analyze the inequality distribution of health workers. The findings showed the ratio of midwives and nurses/100,000 population had met The National Medium Term Development Plan 2010-2014 target. However, the doctors were still far from the target. Analysis by Gini Index indicated the distribution of midwives is better than other health workers. The Nusa Tenggara Region has the highest inequality compared to other regions for doctors, nurses and midwives. By administrative, municipital are more equitable to all types of health workers. Regarding the status of underdeveloped areas, remote borders and islands (DTPK), The Non-DTPK areas are more evenly distributed compared to the DTPK. Ratio per population some health workers are sufficient though are not distributed well. The distribution of
\end{abstract}

Korespondensi:

Asep Hermawani

Puslitbang Upaya Kesehatan Masyarakat, Badan Litbang Kesehatan, JIn Percetakan Negara 29, Jakarta Pusat

E-mail: kang.asep007@gmail.com 
health personnel should not merely use the ratio per population. The other distribution index such as the Gini Index and other distribution measures will provide better policy options.

Keywords: Inequality; Gini Index; Kurva Lorenz;Health workforces

\section{PENDAHULUAN}

Sistem pelayanan kesehatan bergantung pada sumber daya manusia dalam semua aspek agar bisa berjalan secara efektif (Campbell et al., 2013). Tenaga kesehatan dengan jumlah dan kualitas yang memadai sangat penting untuk mencapai indikator kesehatan yang optimal karena secara langsung mempengaruhi kualitas layanan kesehatan yang diberikan (Ghosh, 2014, Narasimhan et al., 2004). Namun, hampir semua negara tanpa melihat tingkat perkembangan sosial-ekonomi, menghadapi masalah dalam distribusi tenaga kesehatan seperti kesulitan dalam pendidikan dan pelatihan, penempatan, retensi dan kinerjanya (WHO, 2016).

World Health Organization (WHO) mengestimasi bahwa untuk mencapai 12 indikator kesehatan masyarakat yaitu keluarga berencana, cakupan perawatan antenatal (ANC), persalinan oleh tenaga kesehatan, imunisasi difteri-pertusis-tetanus 3 (DPT 3), kebiasaan merokok tembakau, air minum, sanitasi, terapi antiretroviral, pengobatan tuberkulosis, operasi katarak, diabetes, dan pengobatan hipertensi sebagai proksi indikator kesehatan dalam Sustainable Development Goals (SDGs) dan Universal Health Coverage, memerlukan rasio minimum tenaga kesehatan sebesar 4,45 (dokter, perawat dan bidan) per 1000 penduduk. Secara global, kekurangan tenaga kesehatan pada 2013 diperkirakan sekitar 17,4 juta, yaitu hampir 2,6 juta adalah dokter, sekitar 9 juta adalah perawat dan bidan, dan sisanya tenaga kesehatan lainnya. Asia Tenggara mengalami kekurangan kebutuhan tenaga kesehatan sebesar 6,9 juta dan Afrika sebesar 4,2 juta (WHO, 2016).

Banyak faktor yang dapat menyebabkan ketimpangan distribusi tenaga kesehatan, salah satunya migrasi tenaga kesehatan antar daerah. Beberapa alasan untuk migrasi diantaranya kebijakan pemerintah dalam tenaga kesehatan, kondisi ekonomi karakteristik individu, faktor keamanan, penghasilan, akses pendidikan anak, pengembangan pengetahuan, daerah dengan lingkungan sosial ekonomi yang lebih baik akan menarik lebih banyak tenaga kesehatan. Demikian pula ketersediaan pekerjaan untuk pasangan merupakan salah satu alasan tenaga kesehatan untuk menetap atau pindah dari fasilitas kesehatan (Dussault and Dubois, 2003, Zurn et al., 2004, Hermawan and Hendarwan, 2018).

Pendayagunaan dan pemerataan SDM kesehatan berkualitas yang masih kurang, pengembangan karier, sistem penghargaan, dan sanksi yang belum tegas merupakan beberapa masalah strategis dalam subsistem SDM Kesehatan yang dihadapi saat ini dan di masa depan (Presiden RI, 2012). Lebih dari 50 tahun Pemerintah Indonesia berupaya untuk melakukan pemerataan tenaga kesehatan. Pada tahun 1960, pemerintah mulai melakukan, mengadakan, mengatur, mengawasi, dan membantu pendidikan tenaga kesehatan, menetapkan penggunaan dan penyebaran tenaga kesehatan pemerintah dan swasta sesuai dengan keperluan masyarakat dengan memperhatikan keseimbangan antara jumlah tenaga yang diperlukan dan tenaga yang tersedia (Presiden RI, 1960). Pada 1988, Pemerintah mewajibkan seluruh dokter, dokter gigi, dan dokter spesialis baik yang telah lulus dari perguruan tinggi dalam negeri maupun luar negeri untuk mengikuti masa bakti (Presiden RI, 1988). Pemerintah melakukan penempatan dokter dan bidan melalui sistem pegawai tidak tetap pada 1991 dan 1994 untuk meningkatkan pemerataan tenaga dokter dan bidan. Mereka ditempatkan di daerah terpencil, dan sebagai insentif mereka memperoleh tunjangan khusus dan prioritas pengangkatan sebagai Pegawai Negeri Sipil (Presiden RI, 1991, Presiden RI, 1994).

Pemerintah menetapkan program pembangunan yang berkeadilan pada tahun 2010 dengan salah satu fokus program adalah pencapaian Millenium Development Goals (MDGs) pada bidang kesehatan yaitu penurunan angka kematian ibu. Program ini menetapkan tentang penempatan tenaga kesehatan strategis di fasilitas kesehatan terutama di puskesmas dan kabupaten/kota (Presiden RI, 2010). Penetapan Inpres tersebut memperkuat Peraturan Menteri Kesehatan (Permenkes) tahun 2007 tentang Penugasan Khusus SDM Kesehatan. Program ini bertujuan untuk meningkatkan akses dan mutu pelayanan kesehatan di sarana pelayanan kesehatan di daerah terpencil, sangat terpencil, tertinggal, perbatasan, pulau-pulau kecil terluar, daerah yang tidak diminati, daerah rawan bencana/ mengalami 
bencana dan konflik sosial serta daerah bermasalah kesehatan (Kementerian Kesehatan RI, 2007). Pemerintah memberikan insentif sesuai dengan tingkat keterpencilan dari tempat penugasannya untuk meningkatkan retensi pegawai dalam penugasan khusus (Kementerian Kesehatan RI, 2010).

Upaya Pemerintah Indonesia dalam distribusi tenaga kesehatan baik jumlah jenis maupun kualitas dirasakan belum memadai. Rasio jumlah dokter pada tahun 2007 di Indonesia adalah 19 per 100.000 penduduk. Jumlah ini masih lebih rendah bila dibandingkan dengan negara lain di The Association of Southeast Asian Nations (ASEAN), seperti Filipina 58 per 100.000 penduduk dan Malaysia 70 per 100.000 (Presiden RI, 2012).

Rasio tenaga kesehatan/populasi adalah salah satu perhitungan yang paling umum digunakan dalam penilaian dan perencanaan layanan kesehatan, karena memungkinkan perbandingan antar wilayah dan subregional dengan ukuran populasi yang berbeda dan mudah dalam perhitungan, tetapi masih menawarkan ketidaksetaraan relatif yang cukup baik (Anand and WHO, 2010). Kurva Lorenz dan Gini Index banyak digunakan untuk menilai distribusi pendapatan dan kekayaan, namun sudah juga diaplikasikan dalam menilai distribusi tenaga kesehatan (Theodorakis et al., 2006, Chen et al., 2014, Xu et al., 2014, Song et al., 2016, Tandi et al., 2015, Wiseman et al., 2017, Sefiddashti et al., 2016). Studi ini mencoba untuk melakukan analisis inequlity maldistribusi tenaga kesehatan dengan mengadaptasi teknik literatur ekonomi mengenai ketidakmerataan pendapatan dengan pengukuran distribusi tenaga kesehatan dengan unit geografi kabupaten/kota di tiap provinsi dan region.

\section{METODE}

Penelitian ini menggunakan 2 sumber data yaitu data tenaga kesehatan (dokter perawat dan bidan) diperoleh dari data rutin Badan Pengembangan dan Pendayagunaan Sumber Daya Manusia Kesehatan (BPPSDM Kesehatan) tahun 2013. Data tersebut berasal dari data rutin yang dikumpulkan dari semua fasilitas kesehatan milik pemerintah baik pusat, provinsi maupun kabupaten/kota. Data kemudian diagregatkan ke level kabupaten sehingga sehingga diperoleh data jumlah dokter, bidan dan perawat tiap kabupaten (497 kabupaten/kota).
Data jumlah penduduk diperoleh dari Lampiran 1 Buku Induk Kode dan Data Wilayah Administrasi Pemerintahan Per Provinsi, Kabupaten/Kota dan Kecamatan Seluruh Indonesia (Kemendagri, 2013). Data kemudian digabung menjadi 1 dataset. Rasio tenaga kesehatan (dokter, bidan dan perawat) tiap kabupaten/kota adalah kalkulasi jumlah masingmasing tenaga kesehatan tiap kabupaten/kota dibagi jumlah penduduk kabupaten/kota tersebut kemudian dikalikan 100.000, sehingga diperoleh data rasio masing-masing tenaga kesehatan (dokter bidan dan perawat)/100.000 penduduk.

Analisis dilakukan menggunakan pendekatan geografis yaitu regional (Sumatera, Jawa dan Bali, Nusatenggara, Kalimantan, Sulawesi, Maluku, dan Papua), provinsi (33 provinsi), dan status daerah tertinggal perbatasan, dan kepulauan (DTPK). Pengukuran ketimpangan (inequality) distribusi tenaga kesehatan (dokter perawat dan bidan), menggunakan kurva lorenz dan Gini Index. Inequality distribusi tenaga kesehatan tingkat provinsi diukur hanya menggunakan Gini Index dan disajikan dengan map, sedangkan inequality per regional diukur dengan kurva lorenz dan Gini Index.

Kurva Lorenz adalah representasi grafis dari proporsionalitas suatu distribusi (persentase kumulatif dari suatu nilai). Kurva Lorenz dibentuk dari semua unsur distribusi dari yang paling penting sampai yang paling tidak penting. Kemudian, setiap elemen diplot berdasarkan persentase kumulatif $X$ dan $Y$, yaitu $X$ adalah persentase kumulatif elemen dan $Y$ menjadi persentase kumulatif populasinya (Lemiere et al., 2011). Gini Index adalah rasio daerah didalam grafik tersebut yang terletak diantara kurva Lorenz dan garis kemerataan sempurna (yang membentuk sudut 45 derajat dari titik 0 dari sumbu y dan $x)(A)$ terhadap daerah segi tiga antara garis kemerataan tersebut dan sumbu $y-x(A+B)$. semakin tinggi nilai Gini Index, yakni mendekati 1 atau semakin menjauh kurva Lorenz dari garis 45 derajat tersebut, semakin besar tingkat ketidakmerataan distribusi.

Nilai Gini Index berada pada rentang 0 sampai 1 yaitu 0 kemerataan sempurna (setiap kabupaten memiliki rasio tenaga kesehatan yang sama) dan 1 jika ketidakmerataan yang sempurna yang berarti bahwa hanya ada satu kabupaten/kota (atau satu regional) yang memiliki tenaga kesehatan. Ide dasar dari perhitungan koefisien Gini berasal dari kurva Lorenz (Fellman, 2012). 
Tabel 1. Jumlah, Rasio Tenaga Kesehatan (Dokter, Bidan dan Perawat), dan Disparitas tiap Kabupaten/Kota

\begin{tabular}{lccc}
\hline Karakteristik Penilaian & Dokter & Bidan & Perawat \\
\hline N & 497 & 497 & 497 \\
Jumlah & 35925 & 120689 & 229480 \\
Rasio /100.000 penduduk & 21,63 & 75,94 & 157,88 \\
Gini Index & 0,45 & 0,40 & 0,46 \\
\hline
\end{tabular}

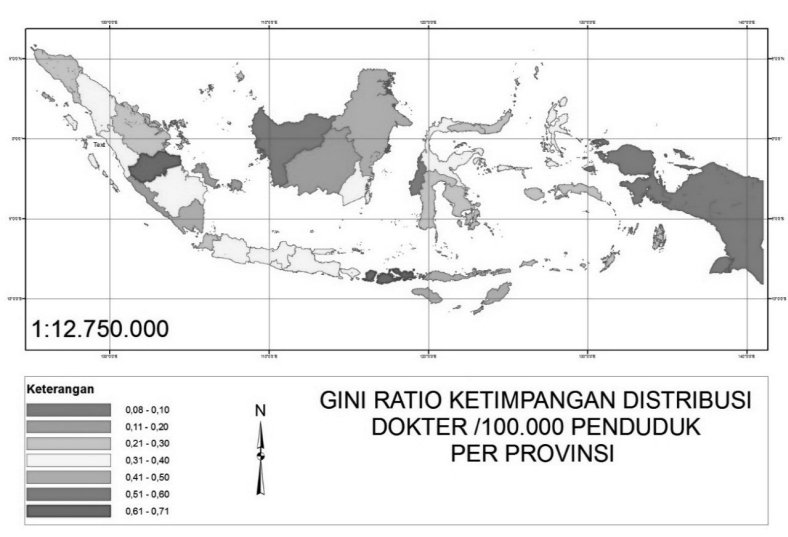

Gambar 1. Gini Index disparitas distribusi tenaga kesehatan Dokter/100.000 penduduk menurut provinsi di Indonesia

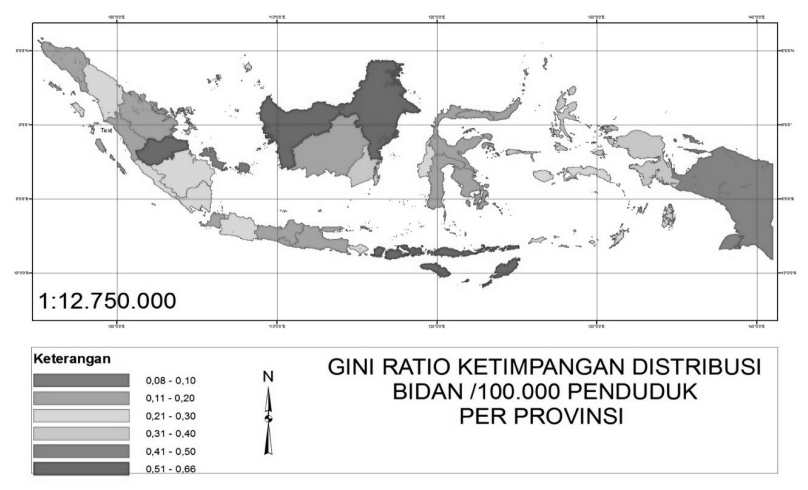

Gambar 2. Gini Index disparitas distribusi tenaga kesehatan bidan per 100.000 penduduk menurut provinsi di Indonesia

\section{HASIL}

Pada Tabel 1, nampak bahwa jumlah dokter di fasilitas kesehatan pemerintah sebanyak 35. 925 orang dari 497 kabupaten kota pada 2013. Rasio dokter /100.000 penduduk sebesar 21,63, dengan Gini Index 0,45. Jumlah bidan maupun rasio bidan/100.000 penduduk secara keseluruhan lebih besar dari dokter. Demikian pula, distribusi bidan sedikit lebih merata dibanding dokter (Gini Index 0,40). Walaupun jumlah (229.480 orang) dan rasionya paling banyak $(157,88)$, namun distribusi perawat paling tidak merata dibandingkan tenaga kesehatan lainnya $(0,46)$. Hasil pengukuran dengan kurva lorenz menunjukkan bahwa rasio perawat memiliki kurva paling jauh dengan garis diagonal (line of equality) dibandingkan dengan kurva rasio dokter dan bidan (Gambar 4A).

Ketimpangan distribusi tenaga kesehatan tiap provinsi dapat dilihat pada Gambar 1 menunjukkan ketimpangan rasio dokter $/ 100.000$ penduduk. Provinsi dengan rasio dokter paling merata $(0,08-0,3)$ terdapat di Provinsi Sulawesi Barat, Kalimantan Tengah, Bengkulu, Kepulauan Bangka Belitung, Gorontalo, Sulawesi Tenggara, Sulawesi Utara, Sulawesi Selatan, Aceh, Riau, Banten, Kepulauan Riau, DKI Jakarta, dan Maluku. Sedangkan Lampung, Nusa Tenggara Timur, Kalimantan Timur, Kalimantan Barat, Papua, Papua Barat, Jambi, dan Nusa Tenggara Barat merupakan provinsi dengan rasio dokter yang paling tidak merata tiap kabupatennya dengan Gini Index> 0,4

Bidan merupakan tenaga kesehatan yang paling terdistribusi dengan baik, sebanyak 24 provinsi memiliki Gini Index sebesar < 0,3. Hanya Papua, Jambi, Nusa Tenggara Timur, Kalimantan Barat, Kalimantan Timur, dan Nusa Tenggara Barat yang memiliki ketimpangan rasio bidan $>4$ (Gambar 2). Sebaliknya perawat merupakan tenaga kesehatan dengan ketimpangan distribusi yang tinggi yaitu Provinsi Bangka Belitung dengan distribusi perawat paling merata $(0,10)$ dan sebaliknya Nusa Tenggara Barat paling tidak merata $(0,70)$. 5 provinsi dengan Gini Index terbaik dalam hal pemerataan perawat adalah Bangka Belitung, Gorontalo, Banten, Bengkulu, dan Sulawesi Tengah, sedangkan 5 provinsi dengan rasio perawat paling tidak merata adalah Nusa Tenggara Timur, Papua, Kalimantan Barat, Jambi, dan Nusa Tenggara Barat (Gambar 3). 


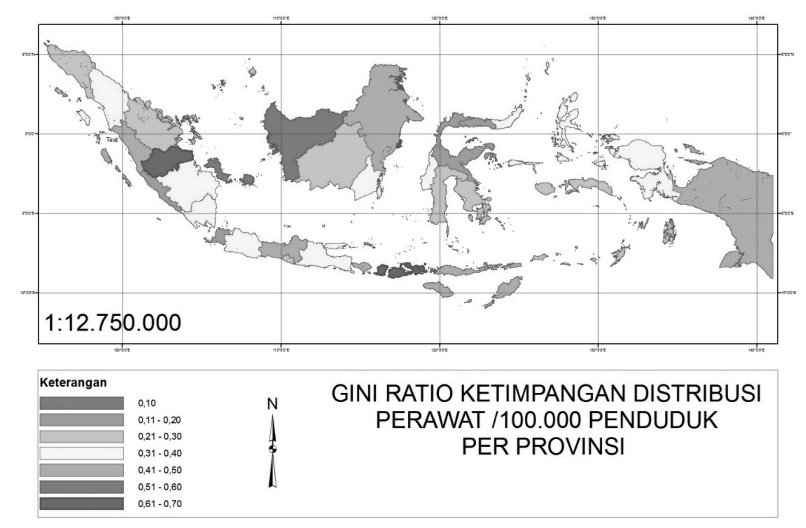

Gambar 3. Gini Index disparitas distribusi tenaga kesehatan perawat / 100.000 penduduk menurut provinsi di Indonesia

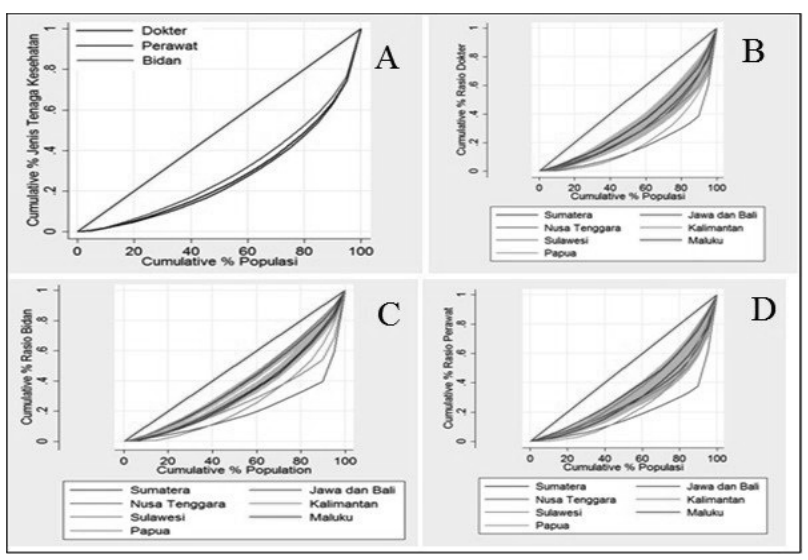

Gambar 4. Kurva Lorenz distribusi rasio tenaga kesehatan per 100.000penduduk secara keseluruhan (A), Dokterper 100.000 penduduk (B), Bidan per 100.000 penduduk $(C)$ dan Perawat per 100.000 penduduk (D) per regional

Tabel 2. Disparitas jumlah tenaga kesehatan Dokter, Bidan dan Perawat antar regional, antara DTPK dan Non DTPK serta antara Kabupaten dengan Kota

\begin{tabular}{lcccc}
\hline \multirow{2}{*}{ Regional } & N & \multicolumn{3}{c}{ Rasio Nakes per 100.000 Penduduk } \\
\cline { 3 - 5 } & & Dokter & Bidan & Perawat \\
\hline Regional & 151 & & & \\
Sumatera & 127 & 16,86 & 97,2 & 140,9 \\
Jawa dan Bali & 31 & 26,39 & 41,97 & 98,83 \\
Nusa Tenggara & 55 & 26,68 & 106,94 & 212,53 \\
Kalimantan & 73 & 18,81 & 103,87 & 246,14 \\
Sulawesi & 20 & 20,47 & 61,49 & 146,24 \\
Maluku & 40 & 29,56 & 70,23 & 267,28 \\
Papua & & & 70,32 & 212,25 \\
\hline Status DTPK & 197 & 22,29 & & \\
$\quad$ DTPK & 300 & 21,19 & 88,43 & 190,77 \\
$\quad$ Non DTPK & & & 67,74 & 136,28 \\
\hline Status Kabupaten/Kota & 399 & 18,00 & & \\
$\quad$ Kabupaten & 98 & 36,40 & 77,06 & 143,86 \\
$\quad$ Kota & 497 & 21,63 & 71,37 & 214,96 \\
$\quad$ Total & & & 75,94 & 157,88 \\
\hline
\end{tabular}

Disparitas tenaga kesehatan antar regional, antara Daerah Tertinggal Perbatasan dan Kepulauan (DTPK) dengan non-DTPK, dan antara kabupaten dengan kota dapat dilihat pada Tabel 2 dan Ttabel 3. Gambar 4B, 4C dan 4D menggambarkan hasil pengukuran kurva lorenz, terlihat bahwa kurva regional Nusatenggara merupakan kurva terjauh dari garis diagonal inequilty yang berarti bahwa regional Nusatenggara adalah regional dengan disparitas distribusi tenaga kesehatan paling tidak merata. Hal ini diperkuat oleh hasil Gini Index yaitu dengan hasil rasio dokter 0,62 , rasio bidan 0,60 dan rasio perawat 0,62 . Hal ini bisa diinterpretasikan bahwa dengan jumlah dokter di fasilitas kesehatan pemerintah di regional ini sebanyak 1080 orang dan rasio dokter 26,39 per 100.000 penduduk, terkonsentrasi di beberapa kabupaten/kota sedangkan banyak kabupaten kota lainya sangat kekurangan, demikian 
Tabel 3. Disparitas jumlah tenaga Dokter, Bidan dan Perawat antar regional, antara DTPK dan Non DTPK dan antara Kabupaten dengan Kota

\begin{tabular}{lcccc}
\hline \multicolumn{1}{c}{ Karakteristik Wilayah } & N & \multicolumn{3}{c}{ Gini Index } \\
\cline { 4 - 5 } & & Dokter & Bidan & Perawat \\
\hline Regional & 151 & 0,42 & 0,34 & 0,42 \\
$\quad$ Sumatera & 127 & 0,42 & 0,23 & 0,42 \\
Jawa dan Bali & 31 & 0,62 & 0,60 & 0,62 \\
Nusa Tenggara & 55 & 0,45 & 0,47 & 0,45 \\
Kalimantan & 73 & 0,31 & 0,21 & 0,31 \\
Sulawesi & 20 & 0,28 & 0,32 & 0,28 \\
Maluku & 40 & 0,48 & 0,46 & 0,48 \\
Papua & & & & 0,49 \\
\hline Status DTPK & 197 & 0,47 & 0,45 & 0,43 \\
DTPK & 300 & 0,43 & 0,35 & 0,47 \\
Non DTPK & & & & 0,41 \\
\hline Status Kabupatenper Kota & 399 & 0,42 & 0,40 & 0,46 \\
Kabupaten & 98 & 0,41 & 0,40 & 0,4 \\
Kota & 497 & 0,45 & & \\
Total & & & & \\
\hline
\end{tabular}

halnya dengan bidan dan perawat yang terkumpul banyak di beberapa kabupaten/kota.

Regional Maluku, walaupun jumlah dokternya paling sedikit jika dibanding dengan regional lainnya namun terdistribusi hampir merata di seluruh kabupaten/kota. Demikian juga dengan distribusi perawat walaupun jumlahnya lebih sedikit dibandingkan regional Papua tapi terdistribusi dengan baik $(\mathrm{Gl} 0,28)$. Distribusi bidan di regional Jawa dan Bali $(G I 0,23)$ serta Sulawesi $(G \mid 0,21)$ memiliki distribusi paling baik diantara regional lainnya. Hal menarik adalah regional Jawa dan Bali, dengan jumlah tenaga kesehatan paling banyak, namun ketika dilihat dari rasio dokter, bidan maupun perawat paling sedikit dibandingkan dengan regional lainnya. Hal ini disebabkan lebih dari 55\% penduduk Indonesia berada di regional ini dan data yang diperoleh berasal hanya dari fasilitas kesehatan pemerintah tidak termasuk swasta, padahal jumlah fasilitas kesehatan swasta jumlahnya lebih banyak di regional Jawa Bali.

Jika dianalisis berdasarkan status DTPK/nonDTPK, tampak bahwa rasio dokter, bidan dan perawat per 100.000 di daerah DTPK lebih tinggi dibandingkan dengan daerah non DTPK. Namun, jika dilihat berdasarkan ketimpangan distribusi kabupaten/ kota yang non DTPK memiliki distribusi tenaga lebih baik (Tabel 2). Jika dianalisis menggunakan status administratif Kabupaten dan Kota, tampak bahwa rasio dokter di kota lebih dari 2 kali lipat dibandingkan dengan rasio dokter di Kabupaten. Demikian pula dengan rasio perawat, hampir 1,5 kali lebih banyak di Kota. Hal menarik adalah rasio bidan/ 100.000 penduduk yang berlaku sebaliknya yaitu lebih banyak di Kabupaten dibandingkan Kota. Disparitas distribusi tenaga antara kota dan kabupaten tidak menunjukkan perbedaan berarti, hanya disparitas rasio perawat yang sedikit berbeda, dimana rasio perawat lebih terdistribusi di Kota $(\mathrm{Gl} 0,41)$ dibandingkan dengan Kabupaten (GI 0,47)

\section{PEMBAHASAN}

Tenaga kesehatan sangat penting untuk memastikan pelayanan kesehatan berfungsi dengan semestinya. Kekurangan dan maldistribusi tenaga kesehatan merupakan masalah umum yang dihadapi banyak negara dan menjadi tantangan dalam peningkatan derajat kesehatan (World Health Organization, 2015). Investasi tenaga kesehatan tetap rendah, dengan kesenjangan besar di antaranya permintaan dan penawaran; perencanaan tenaga kesehatan sering lemah tanpa koordinasi lintas sektoral; kebijakan tentang retensi tenaga kesehatan di daerah rural dan di dalam negara tidak sepenuhnya diimplementasikan; meningkatkan dan 
mentransformasikan pendidikan profesional kesehatan pada tahap awal reformasi (Tangcharoensathien et al., 2015, van de Pas et al., 2018).

Pemerintah Indonesia menganggap bahwa pemerataan tenaga kesehatan mempunyai kontribusi yang besar untuk kesuksesan pembangunan kesehatan di Indonesia (Presiden RI, 2012). Setiap 5 tahun pemerintah (Kementerian Kesehatan) membuat rencana strategis untuk pencapaian distribusi tenaga kesehatan berdasarkan rasio tenaga kesehatan terhadap populasi penduduk. Pada Rencana Strategis (Renstra) Kementerian Kesehatan tahun 2014-2019, Pemerintah Indonesia membuat target rasio dokter umum 48/100.000 penduduk, perawat 158/100.000 penduduk, dan bidan 75/100.000 penduduk (Kementerian Kesehatan RI, 2015). Rasio bidan $75,94 / 100.000$ penduduk dan perawat $157,88 / 100.000$ penduduk sudah terpenuhi pada 2013, namun kondisi kecukupan dokter 21,63/100.000 penduduk masih jauh dari target (48/100.000 penduduk).

Selain mengalami kekurangan dokter, masalah lain adalah distribusinya. Hasil analisis dengan kurva lorenz dan Gini Index bahwa Gini Index distribusi dokter sebesar 0,45 lebih besar dari ketimpangan distribusi bidan $(\mathrm{Gl} 0,40)$, walaupun lebih kecil dari perawat $(0,46)$. Ketimpangan semakin terlihat jika di analisis menurut provinsi. Kalimantan Barat, Papua, Papua Barat, Jambi, dan Nusa Tenggara Barat merupakan provinsi memiliki konsistensi maldistribusi tenaga kesehatan baik dokter, bidan dan perawat. Hal ini menunjukkan bahwa tenaga dokter, bidan dan perawat terkonsentrasi di ibukota provinsi atau kota besar lainya di provinsi tersebut. Secara nasional rasio dokter/penduduk memang masih kurang oleh karena itu dokter memiliki opsi untuk memilih pekerjaan dan tinggal di wilayah urban. (Zhou et al., 2015)

Selain karena jumlah dokter dan perawat di rumah sakit pemerintah di ibukota provinsi yang lebih banyak, ada kemungkinan alasan mengapa tenaga kesehatan (dokter, bidan dan perawat) memilih bekerja di ibukota provinsi diantaranya infrastruktur fasilitas kesehatan, kondisi kerja dan kehidupan yang kurang layak di daerah pinggiran/ rural, dan kesempatan memperoleh tambahan penghasilan dari kerja sampingan di daerah perkotaan atau di daerah kaya. (Heywood and Harahap, 2009) Demikian pula wilayah dengan tingkat sosial ekonomi lebih baik seperti akses terhadap pendidikan laik untuk anak dan ketersediaan lapangan kerja untuk pasangan berpengaruh terhadap pilihan tenaga kesehatan untuk bekerja di daerah tersebut. (Zurn et al., 2004) Ada hal menarik untuk dilihat bahwa beberapa provinsi pemekaran seperti Sulawesi Barat, dan Kepulauan Bangka Belitung $(\mathrm{Gl}<0,1)$ memiliki rasio dokter yang merata di tiap kabupatennya. Walaupun rasio dokter di bawah rata-rata nasional, namun memiliki tingkat inequality yang rendah.

\section{KESIMPULAN DAN SARAN}

\section{Kesimpulan}

Rasio tenaga kesehatan absolut terhadap penduduk masih bervariasi. Rasio dokter per 100.000 penduduk belum mencapai target capaian. Sedangkan rasio perawat dan bidan per 100000 penduduk sudah terpenuhi, namun distribusi nya tidak merata. Hasil analisis menunjukkan bahwa, distribusi bidan merupakan yang terbaik dibandingkan dokter dan perawat. Jambi, Nusa Tenggara Timur, Kalimantan Barat, dan Papua merupakan provinsi dengan tingkat inequality tertinggi untuk dokter dan perawat. Sedangkan untuk bidan inequality tertinggi terjadi di Provinsi Jambi, Nusa Tenggara Timur dan Barat, Kalimantan Barat dan Timur, serta Papua. Secara regional, Regional Nusa Tenggara memiliki inequality tenaga kesehatan tertinggi dibandingkan dengan regional lainnya baik untuk dokter, perawat, dan bidan. Berdasarkan status administratif kabupaten/kota maka, kota cenderung lebih merata untuk semua jenis tenaga kesehatan. Demikian halnya jika dianalisis berdasarkan status DTPK. Daerah non DTPK cenderung lebih merata dibandingkan dengan daerah DTPK.

\section{Saran}

Redistritribusi tenaga bidan dan perawat merupakan hal penting untuk memastikan aksesibilitas pelayanan kesehatan selain penambahan jumlah dokter yang masih kurang. Evaluasi distribusi tenaga kesehatan sebaiknya tidak hanya menggunakan rasio tenaga per populasi saja, penggunaan ukuran indeks distribusi lain seperti Gini Index dan ukuran distribusi lain akan dapat memberi banyak opsi kebijakan yang dipilih.

\section{UCAPAN TERIMA KASIH}

Penulis mengucapkan terimakasih kepada Kepala Badan BPPSDMK yang telah mengijinkan penulis melakukan analisis sebagian data rutin 
tenaga kesehatan, 2013 dan Bapak Drs. Max Joseph Herman Apt., M.Kes yang telah memberikan bimbingan dalam penulisan artikel ini.

\section{DAFTAR PUSTAKA}

Anand, S. \& WHO 2010. Measuring health workforce inequalities: methods and application to China and India. Geneva, Switzerland, WHO Press.

Campbell, J., Dussault, G., Buchan, J., et al. 2013. A universal truth: no health without a workforce. Forum report, Third Global Forum on Human Resources for Health, Recife, Brazil. Geneva, Global Health Workforce Alliance and World Health Organization.

Chen, R., Zhao, Y., Du, J., et al. 2014. Health workforce equity in urban community health service of China. Plos one, 9, e115988.

Dussault, G. \& Dubois, C.-A. 2003. Human resources for health policies: a critical component in health policies. Human resources for health, $1,1$.

Fellman, J. 2012. Estimation of Gini coefficients using Lorenz curves. Journal of Statistical and Econometric Methods, 1, 31-38.

Ghosh, S. 2014. Equity in the utilization of healthcare services in India: evidence from National Sample Survey. International journal of health policy and management, 2, 29.

Hermawan, A. \& Hendarwan, H. 2018. Faktor yang Mempengaruhi Niat Pindah Mahasiswa Peserta Program Bantuan Pendidikan Dokter Spesialis dan Gigi Spesialis. Jurnal Penelitian dan Pengembangan Pelayanan Kesehatan, 1-9.

Heywood, P. F. \& Harahap, N. P. 2009. Human resources for health at the district level in Indonesia: the smoke and mirrors of decentralization. Human Resources for Health, 7, 6.

Kemendagri 2013. Buku Induk Kode dan Data Wilayah Administrasi Pemerintahan Per Provinsi, Kabupaten/ Kota dan Kecamatan Seluruh Indonesia (Lampiran 1). Jakarta. Tersedia pada: http://www.kemendagri.go.id/ media/filemanager/2013/05/28/b/u/buku_induk_ kode_data_dan_wilayah_2013.pdf.

Indonesia. Undang-Undang, Peraturan, dsb. 2007. Peraturan Menteri Kesehatan Republik Indonesia Nomor 1231/ MENKES/PER/XI/2007 Tentang Penugasan Khusus Sumber Daya Manusia Kesehatan. Jakarta.

Indonesia. Undang-Undang, Peraturan, dsb. 2010. Keputusan Menteri Kesehatan Republik Indonesia Nomor 156/Menkes/SK/I/2010 Tentang Pemberian Insentif bagi Tenaga Kesehatan dalam Rangka Penugasan Khusus di Puskesmas Daerah Terpencil, Perbatasan dan Kepulauan. Jakarta.

Indonesia. Undang-Undang, Peraturan, dsb. 2015. Keputusan Menteri Kesehatan R.I. Nomor HK.02.02/ MENKES/52/2015 Tentang Rencana Strategis Kementerian Kesehatan Tahun 2015-2019 Jakarta.
Lemiere, C., Herbst, C. H., Jahanshahi, N., et al. 2011. Reducing Geographical Imbalances of Health Workers in Sub-Saharan Africa: A Labor Market Perspective on What Works, What Does Not, and Why. Washington DC, The World Bank.

Narasimhan, V., Brown, H., Pablos-Mendez, A., et al. 2004. Responding to the global human resources crisis. Lancet, 363, 1469-72.

Indonesia. Undang-Undang, Peraturan, dsb. 1960. Undangundang Republik Indonesia Nomor 9 Tahun 1960 Tentang Pokok-Pokok Kesehatan. Jakarta: Pejabat Sekretaris Negara.

Indonesia. Undang-Undang, Peraturan, dsb. 1988. Peraturan Pemerintah No 1 Tahun 1988 Tentang Masa Bakti dan Praktek Dokter dan Dokter Gigi. tersedia pada https://ropeg.kemkes.go.id/download/ pp198801.pdf.

Indonesia. Undang-Undang, Peraturan, dsb. 1991. Keputusan Presiden Republik Indonesia Nomor 37 Tahun 1991 Tentang Pengangkatan Dokter Sebagai Pegawai Tidak Tetap Selama Masa Bakti. Jakarta, Sekretariat Kabinet RI.

Indonesia. Undang-Undang, Peraturan, dsb.1994. Keputusan Presiden Republik Indonesia Nomor 23 tahun 1994 Tentang Pengangkatan Bidan Sebagai Pegawai Tidak Tetap Jakarta Sekretariat Kabinet RI.

Indonesia. Undang-Undang, Peraturan, dsb. 2010. Instruksi Presiden Republik Indonesia Nomor 3 Tahun 2010 Tentang Program Pembangunan yang Berkeadilan. Tampaksiring: Sekretaris Kabinet.

Indonesia. Undang-Undang, Peraturan, dsb. 2012. Peraturan Presiden Republik Indonesia Nomor 72 Tahun 2012 Tentang Sistem Kesehatan Nasional. Jakarta, Sekertariat Kabinet RI

Sefiddashti, S. E., Arab, M., Ghazanfari, S., et al. 2016. Trends of geographic inequalities in the distribution of human resources in healthcare system: the case of Iran. Electronic physician, 8, 2607.

Song, P., Ren, Z., Chang, X., et al. 2016. Inequality of Paediatric Workforce Distribution in China. International journal of environmental research and public health, 13, 703.

Tandi, T. E., Cho, Y., Akam, A. J.-C., et al. 2015. Cameroon public health sector: shortage and inequalities in geographic distribution of health personnel. International journal for equity in health, 14, 43.

Tangcharoensathien, V., Mills, A. \& Palu, T. 2015 Accelerating health equity: the key role of universal health coverage in the Sustainable Development Goals. BMC medicine, 13, 101

Theodorakis, P. N., Mantzavinis, G. D., Rrumbullaku, L., et al. 2006. Measuring health inequalities in Albania: a focus on the distribution of general practitioners. Human Resources for Health, 4, 5. 
van de Pas, R., Mans, L., Bemelmans, M., et al. 2018. Framing the health workforce agenda beyond economic growth. Int J Health Policy Manag.

WHO 2016. Health Workforce Requirements for Universal Health Coverage and The Sustainable Development Goals. Geneva.

Wiseman, V., Lagarde, M., Batura, N., et al. 2017. Measuring inequalities in the distribution of the Fiji Health Workforce. International Journal for Equity in Health, 16, 115.

World Health Organization 2015. Global Health Workforce Alliance. The Kampala declaration and agenda for global action.
Xu, K., Zhang, K., Wang, D., et al. 2014. Trend in distribution of primary health care professionals in Jiangsu province of eastern China. International journal for equity in health, 13, 117.

Zhou, K., Zhang, X., Ding, Y., et al. 2015. Inequality trends of health workforce in different stages of medical system reform (1985-2011) in China. Human resources for health, 13, 94 .

Zurn, P., Dal Poz, M. R., Stilwell, B., et al. 2004. Imbalance in the health workforce. Human resources for health, $2,13$. 